\title{
Blood borne viral infections in transplantation: Hepatitis viruses and retroviruses
}

RP BRYCE LARKE, MD, DCLSC

\begin{abstract}
RPB LARKE. Blood borne viral infections in transplantation: Hepatitis viruses and retroviruses. Can J Infect Dis 1993;4(Suppl C):20C-25C. Hepatitis viruses B (HBV), C (HCV) and D (HDV) and the retroviruses human immunodeficiency virus (HIV-1) and human T cell lymphotropic virus type I (HTLV-1) and type II (HTLV-II) have been transmitted from infected organ and tissue donors to allograft recipients. Ascertainment of personal risk factors by health questionnaire may exclude volunteer blood donors recently exposed to transmissible diseases who could be in the 'window period' of the infection, when routine serological screening tests are negative. Difficulty in obtaining historical evidence of possible recent exposure from a critically ill prospective organ donor may make the residual risk of infection slightly higher than the risk estimated per unit of transfused products from serologically screened volunteer blood donors. Current estimates of residual risk from transfusion based on United States data are: one in 200,000 units for HBV; one in 2000 to one in 6000 units for HCV; one in 40,000 to one in 60,000 units for HIV-1; and one in 69,272 units for HTLV-I/II. Despite recent improvements in anti-HCV testing, current screening assays underestimate the incidence of transmission and prevalence of HCV infection among immunosup pressed organ recipients; evidence of ongoing HCV infection depends on detection of HCV RNA by polymerase chain reaction. Determination of HIV-1 p24 antigen may facilitate identification of prospective organ donors in the window period of early infection and may enhance serological follow-up of allograft recipients at risk of transplantation-associated HIV-1 infection. Highly sensitive assays that can be completed very rapidly are needed to ensure greater safety for the recipient of an emergency organ transplant, where time to screen a prospective donor for infectious diseases may be extremely limited.
\end{abstract}

Key Words: Hepatitis B virus, Hepatitis C virus, Human immunodeficiency virus, Human T cell lymphotropic virus, Transplantation

\section{Infections virales à diffusion hématogène dans les cas de transplantation: virus de l'hépatite et rétrovirus}

Les virus de l'hépatite B (HBV), C (HCV) et D (HDV) et les rétrovirus que sont le virus de l'immunodéficience humaine (HIV-1) et le virus de la leucémie humaine des cellules T (HTLV-1/II) ont été transmis par les organes ou les tissus infectés de donneurs à des receveurs d'allogreffes. La vérification des facteurs de risque personnels par l'entremise de questionnaires sur la santé pourrait écarter les donneurs de sang volontaires récemment exposés à des maladies transmissibles dont l'infection se trouve en période de latence et dont les épreuves de dépistage sérologique de routine sont de ce fait négatives. La difficulté à obtenir des preuves d'une exposition récente possible chez un donneur d'organe potentiellement très

Departments of Pediatrics and Medical Microbiology/Infectious Diseases, University of Alberta and Canadian Red Cross Society. Blood Transfusion Service, Edmonton, Alberta

Correspondence and reprints: Dr RP Bryce Larke, Canadian Red Cross Society, 8249-114 Street, Edmonton, Alberta T6G 2R8. Telephone (403) 431-0202, Fax (403) 431-0461 
malade, risque d'élever légèrement le risque résiduel d'infection par comparaison au risque estimé par unité de produit sanguin transfusé à partir de donneurs de sang volontaires ayant subi un dépistage sérologique. Les estimations actuelles de risque résiduel provenant de données américaines sur la transfusion sont de 1 pour 200,000 unités à l'égard du HBV, de 1 pour 2,000 à 1 sur 6,000 unités pour le HCV et de 1 à 40,000 à 1 à 60,000 unités pour le HIV-1 et de 1 pour 69,272 unités pour le HTLV-1/II. En dépit des récentes améliorations quant au dépistage anti-HCV, les tests actuels sous-estiment l'incidence de transmission et la prévalence de l'infection au HCV parmi les receveurs d'organes immunosupprimés. La preuve qu'il y a infection au HCV évolutive dépend du dépistage de l'ADN du HCV par la réaction en chaîne de polymérase. La détermination de l'antigène p24 du HIV-1 pourrait faciliter l'identification de donneurs d'organes potentiels qui en sont à la période de latence d'une infection et pourrait améliorer le suivi sérologique des receveurs d'allogreffes à risque à l'égard d'une infection à HCV-1 à la suite d'une transplantation. Des épreuves très sensibles qui peuvent être effectuées très rapidement sont nécessaires pour assurer une plus grande sécurité pour les receveurs de transplantation d'organes d'urgence, lorsque le temps manque pour effectuer un dépistage auprès du donneur potentiel à l'égard de maladies infectieuses.

A LARGE NUMBER OF SOLID ORGAN AND CORNEAL TRANS plant procedures are carried out in Canada each year (Table 1). An undetermined, but probably much larger, number of Canadians receive other soft tissue or bone transplants, based on estimates from the United States (1).

Transmission of various blood borne pathogens from infected organ and tissue donors to the transplant recipient has been reviewed in recent years $(1,2)$. Infectious complications may arise from transplantation of virus-infected organs and tissues even if the recipient has serological evidence of previous exposure to that particular virus, as seen with cytomegalovirus. Previous clinical management of the underlying pathological condition in the transplant recipient may have increased the risk of exposure to certain viral pathogens; for example, the patient with end-stage renal disease may have acquired infection with hepatitis B virus (HBV) or hepatitis $\mathrm{C}$ virus $(\mathrm{HCV})$ as a result of earlier hemodialysis or blood transfusions. In studies of transplantation-associated disease, it may be difficult to distinguish between blood or blood products transfused in the perioperative period and the donor organ or tissue as the source of viral infection.

Current policies and practices in transfusion medicine have made the Canadian blood supply as safe as it can be within the limits of donor honesty and knowledge about risk exposures and the sensitivity of carefully performed state-of-the-art laboratory tests to detect transmissible agents. Obtaining information on recent exposure to infection is essential in the selection process for volunteer blood donors. Those whose personal health questionnaire reveals possible recent contact with a transmissible disease could be in the 'window period' of the infection, when routine serological screening tests are negative; they would thus escape rejection as donors if laboratory tests alone were used to determine acceptability. As a minimum safety measure, potential donors of organs and tissues must be screened serologically for all of the infectious disease markers that apply to volunteer blood donors. However, it may be impossible to question a critically ill prospective organ donor or to otherwise ascertain a donor's risk
TABLE 1

Solid organs and corneas transplanted in Canada, 19891991

\begin{tabular}{lrrrr}
\hline Organ/tissue & 1989 & 1990 & 1991 & Total \\
\hline Kidney & 858 & 838 & 851 & 2547 \\
Liver & 152 & 199 & 225 & 576 \\
Heart/lung & 203 & 226 & 217 & 646 \\
Pancreas & 4 & 4 & 7 & 15 \\
Cornea & 2412 & 2518 & 2103 & 7033 \\
Total & 3629 & 3785 & 3403 & 10,817 \\
\hline
\end{tabular}

factors for recent exposure to hepatitis viruses or retroviruses. Therefore, the residual risk of infection from a serologically screened organ or tissue donor is probably going to be slightly higher than the risk estimated per unit of transfused blood products obtained using current Canadian standards for selection and serological testing of voluntary blood donors.

The relatively short time interval adopted in practice between removal of solid organs from the donor and their transplantation into recipients (Table 2) may necessitate decisions on donor suitability being made on the basis of preliminary serological screening tests only. More sophisticated supplementary or confirmatory tests may have to be completed after a heart, lung or liver has already been transplanted. At the other end of the spectrum, bone may be preserved in a viable state for many months before use as a transplant tissue. Ideally, bone is obtained from living donors who are retested for transmissible diseases three to six months later; the bone is transplanted only if the donors remain serologically free from infection (1).

\section{HEPATITIS VIRUSES TRANSMITTED BY ORGAN AND TISSUE TRANSPLANTS}

In 1954, Shutkin (3) published a report of 'homologous-serum hepatitis' transmitted by a graft of cancellous bone that had been frozen in a tissue bank for five months after removal from a donor who had died of nonhepatic causes. The bone graft recipient developed icteric hepatitis 10 weeks postoperatively but, in the 


$\begin{array}{ll}\text { TABLE } 2 & \\ \text { Time interval adopted in practice between removal of } \\ \text { organ or tissue from donor and transplantation into } \\ \text { recipient }\end{array}$

absence of specific serology at that time, one could not differentiate between HBV and HCV infection.

Well-documented transmission of $\mathrm{HBV}$ by renal transplants was reported by Wolf et al in 1979 (4). Recipients of two kidneys from a donor seropositive for hepatitis B surface antigen (HBsAg) (subtype ay) and hepatitis B e antigen (HBeAg) developed asymptomatic HBV infection with serological markers identical to the donor's within six months of transplant surgery. Neither organ recipient had any blood transfusions in the immediate pretransplant or post-transplant period.

Hepatitis D virus (delta agent), which can replicate only in persons infected with HBV, has also been suspected of transmission by renal transplantation. Both HBsAg-positive recipients of the kidneys from an HBsAg-positive donor reported by Lloveras et al (5) developed fulminant hepatitis. In one recipient, this later proved to be related to superinfection with hepatitis $\mathrm{D}$ virus.

Current enzyme immunoassays (EIA) used for routine serological screening of blood and organ donors for HBsAg are extremely sensitive and specific. The frequency of transfusion-transmitted HBV infection is estimated to be about one in 200,000 per unit of blood or blood product transfused in the United States (6); comparable data have not been reported for Canada. The residual risk of infection from serologically screened organ and tissue donors may be slightly higher than the above rate of one in 200,000 due to the reduced efficiency of eliminating organ donors whose medical history may suggest recent exposure to $\mathrm{HBV}$. Corneas obtained from HBsAg-positive donors have not transmitted infection but the outcome may have been altered by administration of hepatitis B immune globulin and hepatitis $B$ vaccine to the recipients (1).

Despite exclusion of HBsAg-positive blood and organs, the incidence of chronic liver disease after transplantation has not been completely eliminated in allograft recipients. Most of the residual non-A, non-B hepatitis has now been attributed to infection with HCV. A study of cadaver organ donors to the New England Organ Bank between 1986 and 1990 who were screened retrospectively using a first generation EIA for anti-HCV was reported by Pereira et al (7). They re- viewed all recipients of organs from anti-HCV-positive donors for evidence of liver disease. They found that nine of 12 seropositive donors (75\%) transmitted the virus; clinical hepatitis began a mean of 3.8 months after transplantation in 14 of the 21 organ recipients $(67 \%)$. HCV was established as the cause of post-transplantation liver disease in 12 of the 13 organ recipients for whom follow-up serum samples were available; in three of these cases, the relationship was based on HCV RNA detected by polymerase chain reaction (PCR). On the basis of these observations, Pereira et al (7) stated that their organ bank would no longer permit transplantation of non-lifesaving organs such as kidneys or pancreas from donors who tested positive for anti-HCV.

The paper by Pereira et al (7) reporting transmission of HCV by organ transplantation stimulated several letters to the editor of the journal which had published the data. A brief report from Norway provided anecdotal evidence of HCV transmission by frozen bone grafts (8). Other writers questioned the validity of the findings in the original report (9) or challenged the conclusion that the risk of transmitting $\mathrm{HCV}$ by organ transplantation justified discarding the kidneys of $\mathrm{HCV}$-positive donors (10).

To clarify some of the issues arising from their 1991 publication (7), Pereira et al carried out a more intensive study of HCV transmission by organ transplantation, supplementing their first generation EIA results with data from two second generation tests (11). They reviewed evidence that seroconversion to anti-HCV usually occurs within three months of parenteral exposure but may take as long as one year and may be associated with either clearing or persistence of the virus. Viremia may persist in some persons without a sustained anti-HCV response. Detection of HCV RNA in the serum has been accepted as evidence of ongoing viral infection. Although Pereira et al (7) had used PCR to detect HCV RNA in their earlier study, a change in primers for the second study resulted in a $40 \%$ increment in positive tests for HCV RNA among their organ recipients who had liver disease after transplantation (11). Results from the second study indicated that a positive screening test for anti-HCV in cadaveric organ donors was associated with an $82 \%$ likelihood of persistent HCV infection as determined by HCV RNA assays. Among HCV RNA-negative recipients of organs from HCV RNA-positive donors, post-transplantation $\mathrm{HCV}$ infection developed in $100 \%$, irrespective of the presence of post-transplantation liver disease; only $62 \%$ of these recipients developed anti-HCV. Pereira et al (11) concluded that current tests for antibodies to HCV underestimate the incidence of transmission and the prevalence of $\mathrm{HCV}$ infection among immunosuppressed organ recipients.

In response to other investigators who have suggested that organs from anti-HCV-positive donors might be transplanted safely into anti-HCV-positive 
recipients (10), Pereira et al (11) gave several reasons why this practice may not be advisable. First, among recipients of organs from $\mathrm{HCV}$-positive donors, the prevalence of post-transplantation liver disease was the same among those who had anti-HCV before transplantation and those who did not. Second, the antibodies detected by current anti-HCV tests are not neutralizing antibodies and do not confer immunity. Third, the current anti-HCV tests do not reliably predict the presence or absence of HCV RNA in serum before transplantation. Fourth, there is evidence that there is more than one strain of HCV and infection with one strain may not protect against infection with another strain.

Using a first generation EIA to screen blood donors for anti-HCV, Donahue et al (12) estimated the risk of post-transfusion hepatitis $\mathrm{C}$ to be about one per 3300 units transfused in the United States. Kleinman et al (13) screened blood donors using a second generation EIA and supplementary recombinant immunoblot assay (RIBA) and reported improved detection of donors who had potentially infectious HCV RNA as determined by PCR. They concluded that the current risk of transmitting HCV from donors negative by the second generation EIA is very low, in the range of one in 2000 to one in 6000 per unit of blood transfused (13). As noted above, the residual risk of infection from a serologically screened organ or tissue donor may be slightly higher than the risk from volunteer blood donors.

In following recipients of solid organs for evidence of transplantation-associated HCV infection, seroconversion to anti-HCV may be delayed as long as 16 months in some patients, as detected by both screening EIA and supplemental RIBA; actual infection can be established much earlier by demonstrating HCV RNA by PCR. This observed delay in seroconversion is thought to be related to the immunosuppressive therapy given to organ transplant recipients (14). Investigators in Spain reported that $44 \%$ of their patients who were anti-HCVpositive before renal transplantation became seronegative one to five years later (15). They concluded that this may reflect an evanescence of antibody titres in transplant patients or an insufficiency of the anti-HCV test as a follow-up marker of infection.

\section{RETROVIRUSES TRANSMITTED BY ORGAN AND TISSUE TRANSPLANTS}

Recommendations that prospective donors of organs and tissues be screened for human immunodeficiency virus (HIV) infection were first published in 1985 by the World Health Organization (16) and the United States Centers for Disease Control (CDC) (17). Anxiety related to the public's perceived risk of developing the uniformly fatal acquired immunodeficiency syndrome (AIDS) from an HIV-infected blood or organ and tissue donor is disproportionately high relative to the actual very low risk. However, patient concern for the risk of donor-to-recipient transmission of HIV increases as evidence mounts that transplant-related cases can occur and as the number of HIV carriers continues to rise (2). Current estimates indicate that about one in every 250 Americans is infected (6); among Canadians, about one in 1000 may be infected with HIV (D Sutherland, personal communication, 1992).

Most of the reported cases of transplantation-associated HIV infection occurred before routine serological testing of donors was available (18). In 1985, Prompt et al (19) reported transmission of HIV by kidney transplantation. The CDC (20) documented that a bone graft from a living donor transmitted HIV to the recipient who developed AIDS approximately 40 months post-transplant; the donor, who had not been screened for HIV when the bone had been removed, died 29 months later with serologically-proven AIDS. A skin graft was the suspected source of HIV in a recipient who tested seropositive 37 days after grafting; although the donor had been tested for HIV, the skin graft was used before the positive result was available (21). Fatal, acute HIV infection with aplastic anemia developed in the recipient of a liver transplanted under emergency conditions before the donor's positive HIV test result was obtained (22).

An unusual situation occurred in the first published report of HIV transmission by organ transplantation from a donor screened for HIV (23). A blood sample obtained from the donor two days before his death tested negative for HIV antibodies by EIA. By that time, the donor had been transfused with 56 units of blood and blood components. Subsequent testing of post mortem blood and a sample taken at admission to hospital, before any transfusions were given, showed positive results for HIV. Recipients of a kidney and liver from the donor became HIV-positive within three months of the transplantation procedure. The report attributed the false negative HIV antibody result to hemodilution caused by the large number of transfusions the donor received before serum was collected for testing. The authors pointed out the importance of testing for HIV on a blood sample obtained at hospital admission in situations where a donor has subsequently been multiply transfused before the organs and tissues are removed.

A more likely, although still rare, event associated with a false negative HIV antibody test on a donor is procurement of the organs and tissues during the "window period' of HIV infection when routine serological screening tests are negative. Simonds et al (24) have documented thoroughly one such situation in which a male donor was negative on two serum specimens tested for HIV-1 by EIA at the time of organ procurement. Massive hemodilution prior to testing was not a factor since he had received only two units of plasma protein fraction before death. The investigation was undertaken when a woman was identified as HIV-positive some six years after receipt of a bone allograft from this donor. Efforts were made to contact the other 
recipients of the four solid organs and 54 other tissues that had been distributed. All four recipients of his organs (kidneys, heart and liver) and all three recipients of unprocessed fresh frozen bone were infected with HIV-1. The 34 persons who had received other tissues (including two corneas) were all negative for HIV-1 antibody. Spleen cells from the donor that had been frozen since the time of organ and tissue procurement tested positive for HIV-1 by culture and PCR.

In addition to transmission of HIV to recipients of kidney, liver, heart, bone and skin transplants, HIV infection has also been associated with pancreas and bone marrow transplants $(2,18)$. Although HIV has been isolated from tears, cornea and conjunctival epithelium, no cases of HIV transmission by corneal transplantation have been reported even though corneas from HIV-infected donors have been transplanted inadvertently $(1,2,24)$.

From their extensive review of reports of HIV infection in patients with solid organ transplants published before mid-1990, Erice et al (18) have made a number of observations. Among 16 patients who were seronegative for HIV at transplantation, the mean time of progression to AIDS was 32 months; patients included those infected by the donor organ, by blood transfused during the perioperative period or by unknown means. During the first two months after transplantation, several patients developed prolonged, unexplained fevers with splenomegaly, enlarged lymph nodes, abnormal liver function tests, leukopenia, lymphopenia and thrombocytopenia. These clinical findings were attributed to the syndrome of acute infection with HIV. The reviewers concluded that the differential diagnosis of fever of unknown origin occurring within two months of transplantation should include acute HIV infection. An important finding in the review was that HIV infection did not appear to affect adversely the function of the transplanted organ. Clinical management of symptomatic HIV-infected recipients of transplanted organs should include reduced doses of standard immunosuppressive medications, probably because of the inherent immunosuppressive effects of HIV (18).

Serological follow-up of patients who may be at risk of transplantation-associated HIV infection may be enhanced by determination of circulating p 24 HIV- 1 antigen using solid phase antigen capture EIA. Perez et al (25), in a retrospective study of stored frozen serum samples from patients who acquired HIV infection following renal transplantation between 1979 and 1985 , reported that detection of p24 antigen preceded antibody seroconversion by one to six months. HIV antigenemia is characteristically transient, with the p24 antigen decreasing or becoming undetectable as the HIV-1 antibody appears and titre increases (25-27).

Human T cell lymphotropic virus type I (HTLV-I) and type II (HTLV-II) have been transmitted by blood transfusion (28) and therefore potentially by organ and tis- sue transplantation as well. Perez et al (25) reported one confirmed seroconversion among 224 renal transplant patients studied retrospectively at the University of Miami; they did not attempt to differentiate between HTLV-I and HTLV-II in their laboratory assays. No clinical illness attributable to HTLV-I or HTLV-II infection developed in their patient. Adult T cell leukemia and a myelopathy, tropical spastic paraparesis, are linked causally to HTLV-I infection (28). A $4 \%$ lifetime risk of developing either of these diseases has been estimated for a person infected with HTLV-I, but only the myelopathy has been associated directly with transmission of the virus by transfusion (6). Three patients with $\mathrm{T}$ cell hairy-cell leukemia and two patients with a chronic neurodegenerative syndrome have been reported among persons with HTLV-II infection (28). It has been suggested that dialysis and transplant patients with HTLV-I infection need careful follow-up because the natural course of the retroviral infection may change in patients with spontaneous or induced defects in cellular and humoral immunity (25); presumably the same would apply to transplantation-associated HTLVII infection.

Continuing refinements in serological tests for retroviruses have combined with other improvements in the education and selection of blood donors to enhance further the safety of our blood supply $(6,26,28)$. Third generation double antigen sandwich immunoassays can detect HIV antibody up to 13 days earlier than the second generation assay can, and may even be reactive before any band appears in the Western blot (29). While such early HIV antibody detection may further shorten the infectious 'window period', currently estimated to be about 45 days (6), it raises the possibility of diminishing the usefulness of the Western blot to confirm the presence of antibodies during early infection (29). Zaaijer et al (29) detected HIV antigen in all sera that were reactive for antibody by third generation EIA before any band appeared in the Western blot; they advise laboratories to do an HIV antigen test on third generation EIA-positive, Western blot-negative sera.

The residual risk for HIV-1 infection from donor screened blood in the United States is currently estimated to be in the range of one in 40,000 to one in 60,000 per unit transfused and perhaps as low as one in $225,000(6,28)$. The corresponding residual risk for HTLV-I/II is estimated to be one in 69,272 units (28). The screening test now used by most blood banks for HTLV-I is prepared with antigens from the lysate of an HTLV-I cell culture and contains no antigens specific for HTLV-II; there is a need to improve the sensitivity of the EIA screening test to detect HTLV-II infected donors (28).

The risk of retrovirus infection from a serologically screened organ or tissue donor is very low but will likely remain slightly higher than the rates noted above for 
carefully selected blood donors screened for HIV and HTLV-I/II. Canadians can expect to continue to benefit from somewhat lower rates of undetected retroviral infection than those quoted from United States sources for screened donors. Further applied research is needed to develop highly sensitive assays that can be completed very rapidly to ensure greater safety for the recipient of an emergency organ transplant, where time to screen a prospective donor for infectious diseases may be extremely limited.

ACKNOWLEDGEMENTS: I thank the staff of the Human Organ Procurement and Exchange (HOPE) Program, University of Alberta Hospitals, for providing data used in Tables 1 and 2 .

\section{REFERENCES}

1. Kakaiya R, Miller WV, Gudino MD. Tissue transplanttransmitted infections. Transfusion 1991:31:277-84.

2. Gottesdiener KM. Transplanted infections: Donor-to-host transmission with the allograft. Ann Intern Med 1989;110:1001-16.

3. Shutkin NM. Homologous-serum hepatitis following the use of refrigerated bone-bank bone. Report of a case. J Bone Joint Surg [Am] 1954;36:160-2.

4. Wolf JL, Perkins HA, Schreeder MT, Vincenti F. The transplanted kidney as a source of hepatitis B infection. Ann Intern Med 1979;91:412-3.

5. Lloveras J, Monteis J, Sanchez-Tapias JM, et al. Delta agent transmission through renal transplantation with severe hepatitis induction in two HBsAg+ healthy carriers. Transplant Proc 1986;18:467-8.

6. Dodd RY. The risk of transfusion-transmitted infection. N Engl J Med 1992:327:419-21.

7. Pereira BJG, Milford EL, Kirkman RL, Levey AS. Transmission of hepatitis $\mathrm{C}$ virus by organ transplantation. N Engl J Med 1991;325:454-60.

8. Eggen BM. Transmission of HCV by organ transplantation. N Engl J Med 1992;326:411. (Lett)

9. Diethelm AG, Roth D, Ferguson RM, et al. Transmission of HCV by organ transplantation. N Engl J Med 1992;326:410-1. (Lett)

10. Pirsch JD, Belzer FO. Transmission of HCV by organ transplantation. N Engl J Med 1992;326:412. (Lett)

11. Pereira BJG, Milford EL, Kirkman RL, et al. Prevalence of hepatitis $\mathrm{C}$ virus RNA in organ donors positive for hepatitis $\mathrm{C}$ antibody and in the recipients of their organs. N Engl J Med 1992;327:910-5.

12. Donahue JG, Munoz A, Ness PM, et al. The declining risk of post-transfusion hepatitis $\mathrm{C}$ virus infection. N Engl $\mathrm{J}$ Med 1992;327:369-73.

13. Kleinman S, Busch M, Holland P. Post-transfusion hepatitis C virus infection. N Engl J Med 1992;327:1601. (Lett)
14. Sherlock S, Roggendorf MC, Stevens CE, Thomas HC. $\mathrm{HCV}$ : Epidemiology and its role in liver disease. [Poster session discussion]. In: Hepatitis C Virus. Scientific and Clinical Status. Third International Symposium on HCV. Secaucus: Advanced Therapeutics Communications, 1992:47-8.

15. Oliveras A, Lloveras J, Puig JM, et al. Hepatitis C virus in renal transplantation. Transplant Proc 1991:23:2636-7.

16. The acquired immunodeficiency syndrome (AIDS): Memorandum from a WHO meeting. Bull World Health Organ 1985;63:667-72.

17. Centers for Disease Control. Testing donors of organs, tissues, and semen for antibody to human T-lymphotropic virus type III/lymphadenopathyassociated virus. MMWR 1985;34:294.

18. Erice A, Rhame FS, Heussner RC, Dunn DL, Balfour HH Jr. Human immunodeficiency virus infection in patients with solid-organ transplants: Report of five cases and review. Rev Infect Dis 1991;13:537-47.

19. Prompt CA, Reis MM, Grillo FM, et al. Transmission of AIDS virus at renal transplantation. Lancet 1985;ii:672. (Lett)

20. Centers for Disease Control. Transmission of HIV through bone transplantation: Case report and public health recommendations. MMWR 1988;39:597-9.

21. Clarke JA. HIV transmission and skin grafts. Lancet 1987;i:983. (Lett)

22. Samuel D, Castaing D, Adam R, et al. Fatal, acute HIV infection with aplastic anemia, transmitted by liver graft. Lancet 1988;i:1221-2. (Lett)

23. Centers for Disease Control. Human immunodeficiency virus infection transmitted from an organ donor screened for HIV antibody - North Carolina. MMWR 1987;36:306-8.

24. Simonds RJ, Holmberg SD, Hurwitz RL, et al. Transmission of human immunodeficiency virus type 1 from a seronegative organ and tissue donor. N Engl J Med 1992;326:726-32.

25. Perez G, Ortiz-Interian C, Bourgoignie JJ, et al. HIV-1 and HTLV-I infection in renal transplant recipients. J Acquir Immune Defic Syndr 1990;3:35-40.

26. Phair JP, Wolinsky S. Diagnosis of infection with the human immunodeficiency virus. Clin Infect Dis 1992; 15:13-6.

27. Bowen PA, Lobel SA, Caruana RJ, et al. Transmission of human immunodeficiency virus (HIV) by transplantation: Clinical aspects and time course analysis of viral antigenemia and antibody production. Ann Intern Med 1988;108:46-8.

28. Nelson KE, Donahue JG, Munoz A, et al. Transmission of retroviruses from seronegative donors by transfusion during cardiac surgery. A multicenter study of HIV-1 and HTLV-I/II infections. Ann Intern Med 1992;117:554-9.

29. Zaaijer HL, Exel-Oehlers PV, Kraaijeveld T, Altena E, Lelie PN. Early detection of antibodies to HIV-1 by third-generation assays. Lancet 1992;340:770-2. 


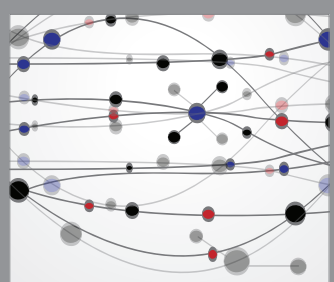

The Scientific World Journal
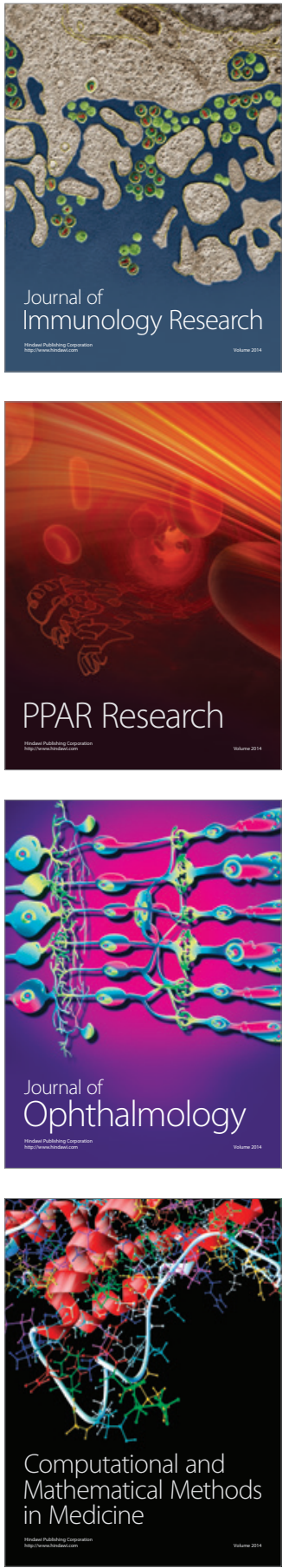

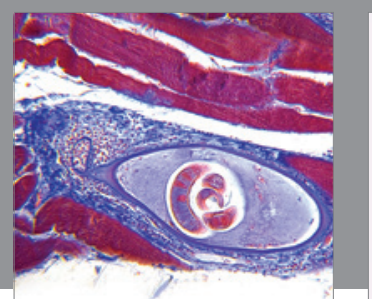

Gastroenterology Research and Practice

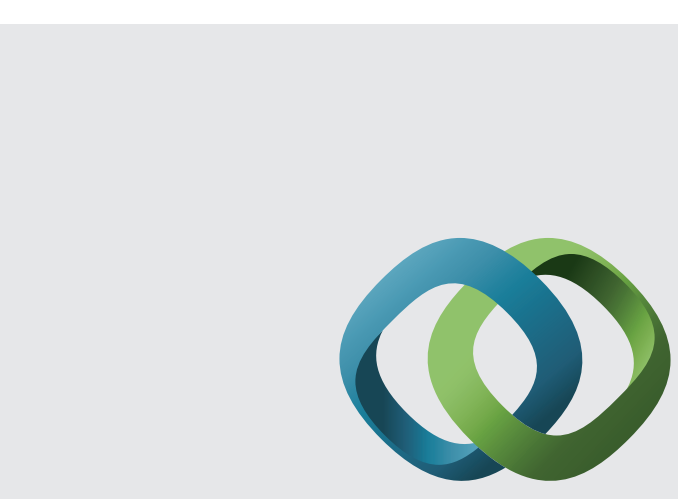

\section{Hindawi}

Submit your manuscripts at

http://www.hindawi.com
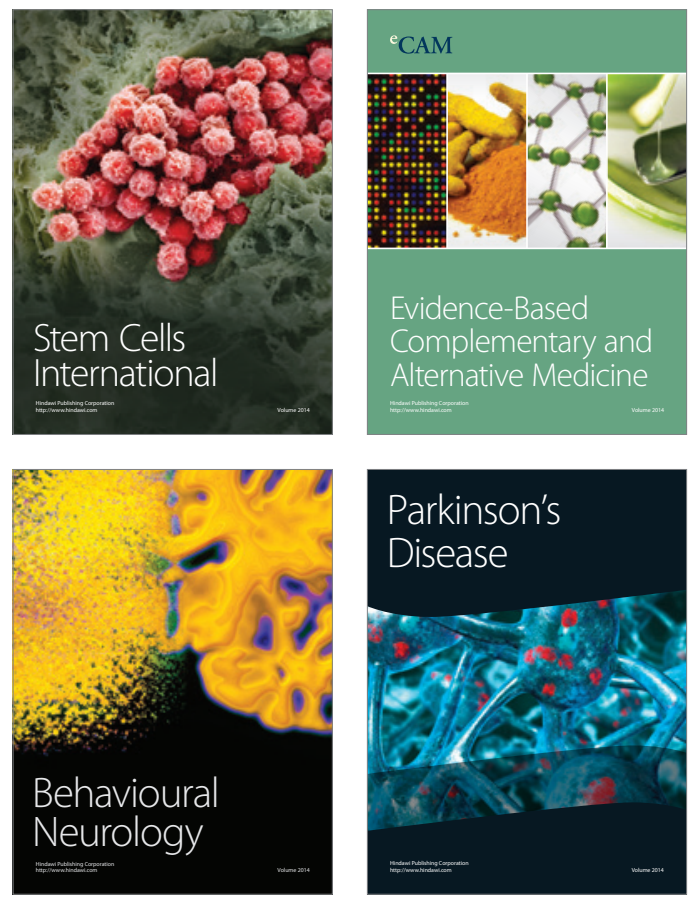
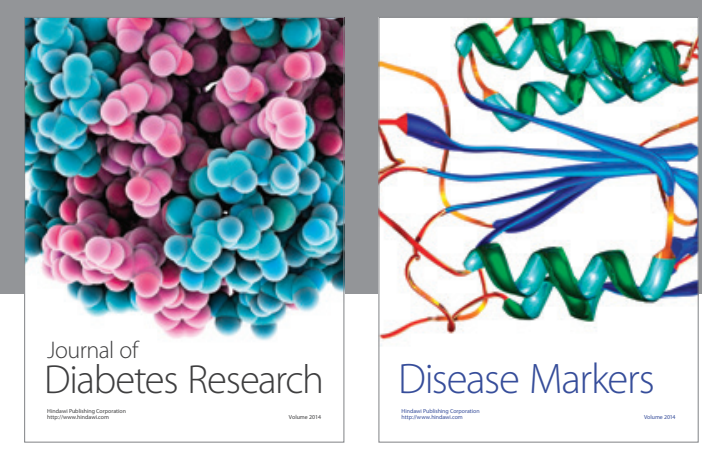

Disease Markers
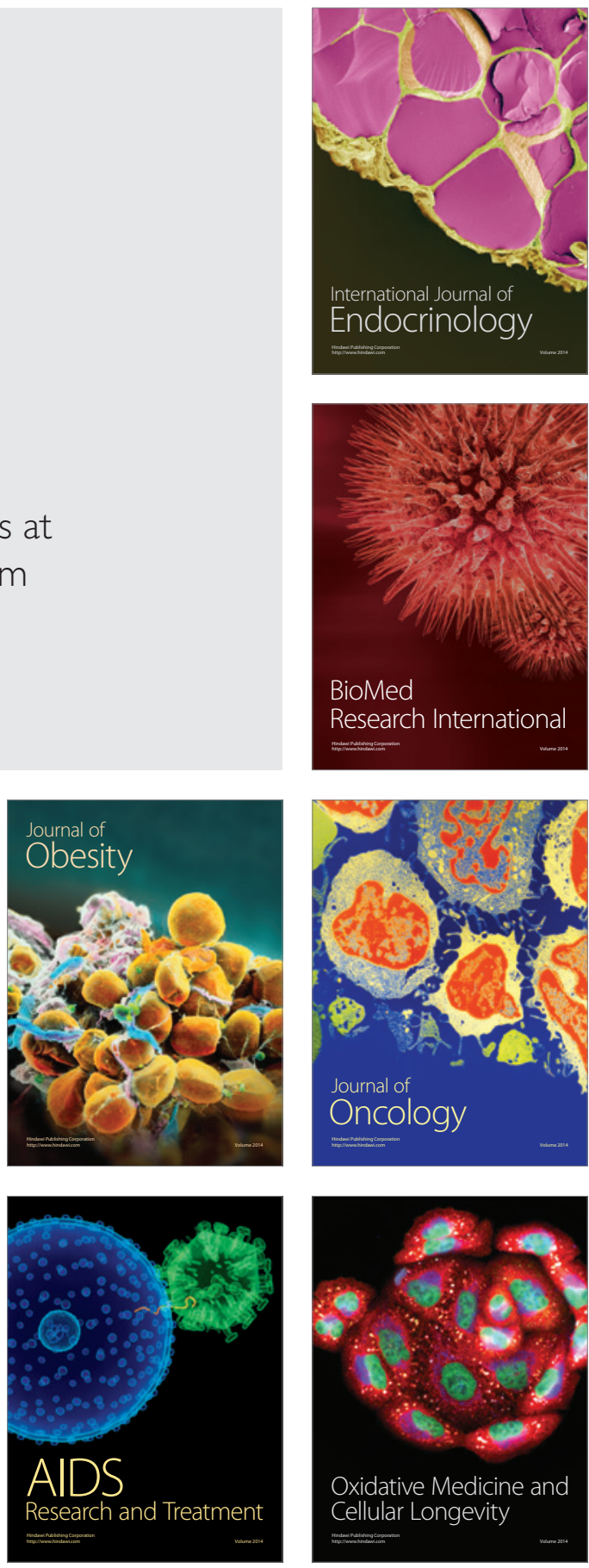